\title{
ЕЛЕКТРОННЕ ПОРТФОЛІО ЯК ФОРМА ПРЕЗЕНТАЦЇ̈ ПРОФЕСІЙНОЇ МАЙСТЕРНОСТІ ПРАЦІВНИКА ЗАКЛАДУ ОСВІТИ
}

\author{
Люшин М. О. \\ кандидат педагогічних наук, \\ завідувач кабінету освітнього адміністрування \\ Рівненський обласний інститут післядипломної педагогічної освіти \\ вул. Чорновола, 74, Рівне, Україна \\ orcid.org/0000-0003-1523-6529 \\ m-ljushyn@ukr.net \\ Люшина В. М. \\ методист кабінету математики та технологій, \\ старший викладач кафедри природничо-математичної освіти \\ Рівненський обласний інститут післядипломної педагогічної освіти \\ вул. Чорновола, 74, Рівне, Україна \\ orcid.org/0000-0002-9109-094X \\ zhalobna69@ukr.net
}

\begin{abstract}
Ключові слова: індивідуальний (суб'єктний) досвід, методична діяльність, онлайн-інструменти, післядипломна педагогічна освіта, предметнометодична компетентність, проєктування, професійний розвиток, технологія науковометодичного супроводу.
\end{abstract}

Розглянуто сутність та особливості електронного портфоліо (далі е-портфоліо) викладача/вчителя як технології фіксування результату його професійного розвитку. Визначено методичні підходи до конструювання та використання портфоліо за технологією науково-методичного супроводу з метою впровадження в практику післядипломної педагогічної освіти. У нашому розумінні е-портфоліо - сформована викладачем/ учителем в електронному вигляді добірка матеріалів, що свідчить про його педагогічну майстерність.

Запропоновано структуру е-портфоліо, яка співвідноситься 3 трьома рівнями методичної діяльності викладача/вчителя (проєктувальним, виконавським, рефлексивним) і дає можливість фахівцю відповідально й творчо підійти до узагальнення, систематизації та презентації набутого професійного досвіду. Е-портфоліо демонструє стиль та вміння педагогічного, науково-педагогічного працівника закладу освіти вибирати стратегію і тактику професійної поведінки, а також дає змогу проаналізувати власні можливості та досягнення і краще підготуватися до реалізації певних функцій, як-от: тьютора, ментора, консультанта, коуча, фасилітатора.

У процесі теоретичного дослідження проблеми та за результатами аналізу педагогічної практики з'ясовано, що електронний варіант портфоліо це публічна інформація, яка працює на викладача/вчителя, може стати підгрунтям для участі в конкурсних, грантових програмах і має низку переваг: поліфункціональність, оперативність, яскравість, наочність, інтерактивність, ергономічність, відкритість і прозорість.

Пропонована методика конструювання е-портфоліо характеризується єдністю умов, мети, змісту, форм, методів, прийомів, технологій і засобів, зокрема онлайн-інструментів, орієнтованих на оцінювання роботи викладача/вчителя із самоосвіти, характеру його діяльності, відстеження творчого і професійного зростання, сприяння формуванню навичок рефлексії (самооцінки).

Виконане дослідження не вичерпує усіх аспектів проблеми, зокрема подальшого вивчення потребують питання розроблення дієвих механізмів формування й оцінювання е-портфоліо викладачів/учителів за освітніми галузями (технологічною, інформатичною, соціальною і здоров’язбережувальною, громадянською та історичною тощо). 


\title{
ELECTRONIC PORTFOLIO AS A FORM OF PRESENTATION OF PROFESSIONAL SKILLS OF EMPLOYEES OF EDUCATIONAL INSTITUTIONS
}

\author{
Liushyn M. O. \\ PhD in Pedagogy, \\ Head of the Education Administration Office \\ Rivne Regional Institute of Postgraduate Pedagogical Education \\ Chornovola str., 74, Rivne, Ukraine \\ orcid.org/0000-0003-1523-6529 \\ m-ljushyn@ukr.net \\ Liushyna V. M. \\ Methodist at the Cabinet of Mathematics and Technology, \\ Senior Lecturer at the Department of Natural and Mathematical Education \\ Rivne Regional Institute of Postgraduate Pedagogical Education \\ Chornovola str., 74, Rivne, Ukraine \\ orcid.org/0000-0002-9109-094X \\ zhalobna69@ukr.net
}

Key words: individual

(subjective) experience, methodological activity, online tools, postgraduate pedagogical education, subjectmethodical competence, design, development, technology of scientific and methodological support.
The essence and features of the electronic portfolio (hereinafter referred to as the e-portfolio) of a lecturer / a teacher as a technology for recording the result of his/her professional development are considered. Methodological approaches to the design and use of a portfolio based on the technology of scientific and methodological support for the implementation of postgraduate pedagogical education in practice are determined. In our understanding, the e-portfolio is a collection of materials formed by a lecturer / a teacher in electronic form, which reflects his/her pedagogical skills.

The structure of the e-portfolio is proposed, which correlates with the three levels of a lecturer's / a teacher's methodological activity (designing, executive, reflexive) and allows the specialist to responsibly and creatively approach the generalization, systematization and presentation of the acquired professional experience. E-portfolio also allows analyzing your own capabilities and achievements and better preparing for the implementation of the following functions: tutor, mentor, consultant, coach, facilitator. It demonstrates the style and ability of a pedagogical, scientific and pedagogical employee of an educational institution in choosing a strategy and tactics of professional behavior. In the process of theoretical research of the problem and based on the results of the analysis of pedagogical practice, it was established that the electronic version of the portfolio is public information which works for a lecturer / a teacher, can become the basis for participation in competitive, grant programs and has a number of advantages: multi-functionality, efficiency, brightness, visibility, interactivity, ergonomics, openness and transparency.

The proposed methodology for constructing an e-portfolio is characterized by the unity of conditions, purpose, content, forms, methods, techniques, technologies and means (in particular, online tools) aimed at assessing the work of a lecturer / a teacher in self-education, the nature of his/her activities, tracking creative and professional growth, promoting the formation of reflection skills (self-esteem).

The study does not exhaust all aspects of the problem, in particular, further study requires the development of effective mechanisms for the formation and assessment of portfolios of lecturers / teachers in educational sectors (technology, information, social and health care, civil and historical, etc.). 
Постановка проблеми. Зміни у суспільній структурі країни, соціокультурних процесах, модернізація освіти висувають нові вимоги до професії викладача/вчителя. Сучасні виклики щодо розвитку національної освіти і ролі педагогічних кадрів актуалізують підвищення престижу педагогічної професії в суспільстві, потреби ринку праці у висококваліфікованих компетентних фахівцях, здатних до дослідницької, предметно-професійної діяльності, впровадження й використання новітніх технологій. Значну роль у неперервному фаховому саморозвитку, самовдосконаленні й творчій самореалізації відіграє е-портфоліо викладача/вчителя як «структурований програмно-методичний комплекс матеріалів, створений із використанням комп'ютерних технологій на основі результатів педагогічних досягнень» [7]. У портфоліо педагог може відобразити всі свої професійні здобутки, показати знання й навички, рівень володіння методикою та сучасними інформаційними технологіями. Портфоліо дає широке уявлення про динаміку творчої активності особистості, спрямованість ії інтересів.

Питання застосування системи портфоліо в освіті залишається предметом дослідження багатьох зарубіжних і вітчизняних науковців та педагогів-практиків. Зокрема, Л. Варченко-Троценко, Н. Морзе розглядають е-портфоліо як інструмент вимірювання результатів діяльності викладача сучасного закладу вищої освіти; Л. Гусак, Н. Сікора - як засіб розвитку інноваційної особистості; О. Бойко, О. Перехейда - як сучасну технологію оцінювання досягнень викладача/вчителя; Л. Гризун, І. Кузьменчук, В. Токар, С. Юхимчук-Шевчик - як індивідуальну траєкторію підвищення кваліфікації педагога; О. Жадан, В. Назаренко, Л. Назаренко, С. Одайник - як чинник успішної атестації педагогічного працівника та ін.

Проте вивчення літератури й аналіз сучасної педагогічної практики доводять відсутність комплексного дослідження методики створення та використання е-портфоліо викладача/вчителя, зокрема не визначено освітній потенціал е-портфоліо, не конкретизовано методичні шляхи його проєктування у післядипломній педагогічній освіті тощо.

Мета статті полягає у з'ясуванні сутності й особливостей е-портфоліо, визначенні методичних підходів до його конструювання та використання 3 позицій презентації педагогічної майстерності сучасного викладача/вчителя.

Виклад основного матеріалу дослідження. Нормативне поле освітньої галузі передбачає виконання викладачем/учителем навчальної, виховної, методичної, організаційної роботи та іншої педагогічної діяльності. Пріоритет у розвитку професіоналізму фахівців сфери освіти відведено методичній діяльності.
Розглядаючи складники методичної діяльності, слід зауважити, що іiі результат має двоякий характер: якщо для здобувача освіти він проявляється у набутті предметної компетентності, то для викладача/вчителя-у набутті його предметно-методичної компетентності. В означенні предметно-методичної компетентності викладача/вчителя доцільно, на думку науковців, перелічувати не всі ії структурні елементи, а один системоутворювальний (головний) [8, с. 144]. Ми погоджуємося 3 думкою вчених у тому, що таким системоутворювальним елементом предметно-методичної компетентності викладача/вчителя є індивідуальний (суб'єктний) досвід здійснення методичної діяльності.

За визначенням Т. Гончаренко, I. Коробової, В. Шарко, предметно-методична компетентність викладача/вчителя - це інтегральна якість особистості, іiі суб'єктний досвід, який дає змогу викладачу/вчителю через систему методичних компетенцій (інформаційних, комунікативних, організаційних, контрольно-оцінювальних) ефективно та якісно здійснювати на проєктувальному, виконавському, рефлексивному рівнях методичну діяльність, спрямовану на організацію процесу засвоєння здобувачами освіти навчального курсу/ предмета. Відповідно, внутрішня структура предметно-методичної компетентності викладача/вчителя маєспіввідноситисязі структуроюсуб' єктного (індивідуального) досвіду особистості. Практика доводить необхідність виконання викладачем/ учителем таких нових для нього функцій: тьютора, ментора, консультанта, коуча, фасилітатора.

Отже, виникає необхідність фіксування й оцінювання набутого викладачем/учителем індивідуального досвіду методичної діяльності. Огляд науково-методичних джерел дає можливість стверджувати, що для реалізації таких процедур може слугувати технологія «методичного портфоліо». За такої умови звертають на себе увагу положення про те, що не існує єдиної мети створення портфоліо. Спираючись на думку В. Шарко та представників іiї наукової школи щодо технологій формування предметно-методичної компетентності, ми розглядаємо методичне портфоліо як форму презентації професійної майстерності педагогічного, науково-педагогічного працівника закладу освіти.

Ідея застосування портфоліо у сфері освіти виникла в американській школі в середині 80 -х років XX ст. як альтернатива тестовій перевірці знань і незабаром стала популярною серед педагогів Свропи та Японії. У 1990-х роках портфоліо привернуло увагу представників пострадянської системи освіти, зокрема й України. Розв'язання проблеми неперервного професійного розвитку педагога у вітчизняній післядипломній освіті може бути здійснено за умови цілеспрямованого використання можливостей 
інформаційно-комунікаційних технологій (далі ІКТ) як засобів інформаційного суспільства. Досвід застосування ІКТ указує не лише на доцільність навчального аспекту мережевої взаємодії, а й на можливість створення е-портфоліо - сформованої викладачем/вчителем в електронному варіанті добірки матеріалів, що свідчить про його педагогічну майстерність. Так, у міжатестаційний період IКТ допомагають і викладачеві/вчителеві, і адміністрації здійснювати моніторинг результатів професійного саморозвитку. Для цього е-портфоліо у вигляді електронного альбому структуруємо за напрямами, з якими співвідносяться відповідні папки, створені у «хмарі» [4, с. 49]. За покликаннями до них поступово завантажуємо відповідні матеріали, які можуть містити: інформацію про професійні здобутки, академічні успіхи здобувачів освіти, творчий доробок (проєкти, публікації, мультимедійні презентації, виступи на семінарах, конференціях); авторські розробки навчальних занять, дидактичних ігор, сценаріїв тощо; аналізи відвіданих навчальних занять, самоаналізи проведених навчальних занять, позанавчальних заходів; дизайнерські рішення оформлення аудиторії/класної кімнати, робочого місця; гіперпокликання на власний вебсайт, блог, сторінку в соціальній мережі (за наявності), фото-, відео-, текстові чи інші матеріали. Заслуговує на увагу такий перелік рубрик е-портфоліо: «Відомості про викладача/ вчителя» (або «Візитна картка»), «Результати педагогічної діяльності», «Науково-методична діяльність», «Позааудиторна/позаурочна діяльність», «Громадська діяльність», «Факти, які варто згадати» [2; 6]. До основних компонентів е-портфоліо відносимо також перелік сертифікатів, грамот, дипломів, інших нагород, звіти, есе «Моя педагогіка», «Історія успіху», «Погляд у майбутнє» тощо. Деякі з означених вище матеріалів можуть мати позначку «Моє улюблене навчальне заняття», «Моя улюблена задача», «Мій найвдаліший/найуспішніший проєкт» тощо.

Електронний варіант портфоліо - це публічна інформація, яка працює на викладача/вчителя, може стати підгрунтям для участі в конкурсних, грантових програмах і має низку переваг, як-от: поліфункціональність (діагностична, мотиваційна, розвивальна, рейтингова та інші функції), оперативність (швидке оновлення даних, можливість миттєвого переходу від одного розділу до іншого), яскравість, наочність, інтерактивність; ергономічність (зручність, комфортність під час використання), відкритість і прозорість. Однак зауважимо, що в е-портфоліо не зазначають дату народження, домашню адресу, телефон, інші персональні дані, пов'язані із захистом права на невтручання в особисте життя.
За метою створення виокремлюють такі різновиди портфоліо:

- портфоліо документації: мета - створити набір документів, необхідних у роботі;

- презентаційне портфоліо: мета - продемонструвати іншим процес і досягнення у своїй діяльності за раніше представленими розділами;

- оціночне портфоліо: мета - дати можливість собі та іншим оцінити власну діяльність;

- портфоліо робіт (робоче портфоліо): мета показати різноманітність і рівень своєї діяльності;

- портфоліо процесу: мета - відобразити процес і динаміку роботи для досягнення поставлених цілей;

- проблемно-дослідницьке портфоліо: мета презентувати свої досягнення у науково-дослідницькій роботі [8, с. 189].

Аналіз теоретичних джерел та педагогічної практики зумовив необхідність розкрити принципи проєктування електронного варіанта портфоліо. Визначимо правила укладання е-портфоліо:

1. Якомога точніше сформулювати мету складання е-портфоліо, самокритично оцінивши свої можливості та здібності.

2. Визначити модель е-портфоліо, види рефлексії та критерії оцінювання. Грамотно структуроване портфоліо передусім відповідає на запитання «Як?» і тільки після того - на запитання «Що?» [2, c. 14].

3. Зібрати наявні матеріали й розташувати їх у певному порядку, скласти перелік. Матеріали у будь-якому портфоліо датуються.

4. Вибрати онлайн-інструменти для створення портфоліо (Blogger, Crello, Google Sites, Prezi, Tilda, Webnode, Wix та ін.).

5. Періодично поповнювати е-портфоліо відповідними документами й відстежувати результати роботи згідно з поставленими цілями.

6. Указувати джерела використання інформації для роботи, описувати засоби, прийоми, методи, технології, методики роботи [6, с. 14].

Зважаючи на викладене вище, звертаємо увагу на такі вимоги до укладання е-портфоліо: системність і регулятивність самомоніторингу; повнота і різноманітність матеріалів, що відображають основні напрями та види діяльності викладача/вчителя; послідовність; достовірність; об'єктивність; націленість автора на самовдосконалення; структуризація матеріалів (наявність чітких розділів/рубрик, логічність і лаконічність усіх письмових пояснень); охайність і естетичність оформлення; цілісність, тематична завершеність представлених матеріалів; наочність результатів роботи; технологічність.

Помилковими підходами до формування е-портфоліо є: порушення принципу добровільності під час збирання документів і формування портфоліо; збирання матеріалів за чиїмось дору- 
ченням; заформалізованість і беззмістовне змагання під час укладання портфоліо; наявність у портфоліо тільки офіційних документів [6, с. 13].

У контексті зазначеного адаптовані методичні підходи дають можливість розглядати е-портфоліо як один із методів професійного розвитку викладача/вчителя, адже портфоліо дає змогу перейти від адміністративної системи вивчення результативності педагогічної діяльності до розроблення власної траєкторії досягнень педагога. Водночас ми погоджуємося з думкою фахівців, що технологія портфоліо не є досконалою. Головний іiі недолік - значна систематична робота викладача/вчителя з високою кваліфікацією і великим бажанням працювати з е-портфоліо.

Висновки та перспективи подальших досліджень. Таким чином, попри те, що проєктування е-портфоліо вимагає дотримання низки методичних принципів і вимог, воно є індивідуальним творчим проєктом, сучасним поглядом викладача/вчителя на презентацію власного професіоналізму. Е-портфоліо дає можливість фахівцеві відповідально проаналізувати свої можливості та досягнення, краще сформувати навички рефлексії (самооцінки), продемонструвати стиль та вміння викладача/вчителя вибирати стратегію і тактику професійної поведінки.

Виконанедослідження невичерпуєусіх аспектів проблеми, зокрема подальшого вивчення потребують питання розроблення дієвих механізмів формування й оцінювання е-портфоліо викладачів/ учителів за освітніми галузями (технологічною, інформатичною, соціальною і здоров'язбережувальною, громадянською та історичною тощо).

\section{ЛIТЕРАТУРА}

1. Бойко О.І. Електронне портфоліо викладача - альтернативна форма оцінки його педагогічної діяльності та професіоналізму. Вісник Черкаського державного технологічного університету. Технічні науки. 2017. № 1. С. 150-155.

2. Кузьменчук I. Портфоліо як індивідуальна траєкторія підвищення кваліфікації педагога. Всесвітня література в школах Украӥни. 2015. № 3. С. 12-17.

3. Морзе Н.В., Варченко-Троценко Л.О. Електронне портфоліо як інструмент вимірювання результатів діяльності викладача сучасного ВНЗ. Інформатика та інформачійні технології в навчальних закладах. 2014. № 53. С. 36-41.

4. Назаренко В.С., Назаренко Л.М., Одайник С.Ф. Професійний успіх педагога як соціально-педагогічна проблема : у 2-х ч. Ч. 2. Харків : Основа, 2015. 80 с.

5. Перехейда О.М. Портфоліо як сучасна технологія оцінювання досягнень. Управління школою. 2017. № 16-18. С. 85-92.

6. Сікора Н.М. Портфоліо вчителя. Англійська мова та література. 2020. № 13-15. С. 10-15.

7. Фамілярська Л.Л. Особливості створення вчителем електронного портфоліо. Житомирщина педагогічна. 2019. № 1. URL: https://imso.zippo.net.ua/wp-content/uploads/2019/04/familyarskayaE-portfolio.pdf (дата звернення: 28.04.2021).

8. Шарко В.Д., Коробова В.І., Гончаренко Т.Л. Нові технології в шкільній і вузівській дидактиці фізики : монографія / за ред. В.Д. Шарко. Херсон : Грінь Д.С., 2015. 258 с.

9. Юрійчук І. Як створити зразкове е-портфоліо: 4 підказки. Практика управління закладом освіти. 2019. № 7. C. 22-24.

\section{REFERENCES}

1. Boiko O.I. (2017). Elektronne portfolio vykladacha - alternatyvna forma otsinky yoho pedahohichnoi diialnosti ta profesionalizmu [An electronic portfolio of a teacher is an alternative form of evaluation of his/her pedagogical activity and professionalism]. Bulletin of Cherkasy State Technological University. Technical Sciences. Vol. 1. P. 150-155.

2. Kuzmenchuk I. (2015). Portfolio yak indyvidualna traiektoriia pidvyshchennia kvalifikatsii pedahoha [Portfolio as an individual trajectory of teacher training]. World literature in schools of Ukraine. Vol. 3. P. 12-17.

3. Morze N.V., Varchenko-Trotsenko L.O. (2014). Elektronne portfolio yak instrument vymiriuvannia rezultativ diialnosti vykladacha suchasnoho VNZ [Electronic portfolio as a tool for measuring the performance of a teacher of a modern university]. Informatics and information technologies in educational institutions. Vol. 53. P. 36-41.

4. Nazarenko V.S., Nazarenko L.M., Odainyk S.F. (2015). Profesiinyi uspikh pedahoha yak sotsialno-pedahohichna problema [Professional success of a teacher as a socio-pedagogical problem]: in 2 parts. Part 2. Kharkiv: Publishing Group "Osnova" [in Ukrainian].

5. Perekheida O.M. (2017). Portfolio yak suchasna tekhnolohiia otsiniuvannia dosiahnen [Portfolio as a modern technology for evaluating achievements]. School management. Vol. 16-18. P. 85-92. 
6. Sikora N.M. (2020). Portfolio vchytelia [Teacher's Portfolio]. English Language and Literature. Vol. 13-15. P. 10-15.

7. Familiarska L.L. (2019). Osoblyvosti stvorennia vchytelem elektronnoho portfolio [Peculiarities of creating an electronic portfolio by a teacher]. Zhytomyr Region Pedagogical. Vol. 1. Retrieved from https://imso.zippo.net.ua/wp-content/uploads/2019/04/familyarskaya-E-portfolio.pdf [in Ukrainian].

8. Sharko V.D., Korobova V.I., Honcharenko T.L. (2015). Novi tekhnolohii v shkilnii i vuzivskii dydaktytsi fizyky: monohrafiia [New technologies in school and university didactics of physics: monograph]. Kherson: EE Hrin D.S. [in Ukrainian].

9. Yuriichuk I. (2019). Yak stvoryty zrazkove e-portfolio: 4 pidkazky [How to create an exemplary e-portfolio: 4 tips]. Practice of managing an educational institution. Vol. 7. P. 22 -24. 